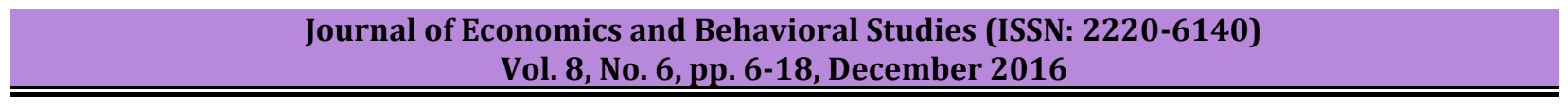

\title{
Examining the Moderating Effect of Environmental Hostility on the Entrepreneurial Orientation - Performance Relationship
}

\author{
Neneh Brownhilder \\ Universiteit Van Die Vrystaat Bloemfontein, South Africa \\ brahilder@gmail.com
}

\begin{abstract}
While the E0-performance nexus has received extensive attention in entrepreneurship literature, other studies suggest that the magnitude of this relationship is dependent upon the external environment and internal organizational processes. The objective of this study was to measure the effects of EO (innovativeness, risk-taking, proactiveness, autonomy and competitive aggressiveness) on SME performance, as well as to examine the moderating effect of environmental hostility on the EO-performance relationship in South Africa. The study showed thatwhile innovativeness and proactiveness does not have a significant effect on SME performance; risk taking propensity, competitive aggressiveness, and autonomy have a significant positive effect on SME performance. It was also seen that while the risk taking-performance relationship is negatively moderated by environmental hostility, the competitive aggressiveness-performance relationship is positively moderated by environmental hostility. This suggest the need for SMEs to always align their business strategies with appropriate EO dimensions to mitigate some of the negative consequences of operating in hostile business environments and improve the performance of their businesses.
\end{abstract}

Keywords: Entrepreneurial orientation, SME performance, Environmental Hostility, South Africa

\section{Introduction}

In today's vibrant and ever changing business environment, entrepreneurial orientation (EO) has gain significant recognition as a key ingredient that business can adopt to survive and grow as evident from existing strategy literature (Baker \& Sinkula, 2009; Rauch et al., 2009; Liu et al., 2011; Runyan et al., 2008). EO has been found to be a vital ingredient for organizational success and a key factor in enhancing firm performance (Rauch et al., 2009; Wiklund \& Shepherd, 2005). According to Rauch et al. (2009: 763) "EO represents the policies and practices that provide a basis for entrepreneurial decisions and actions". EO also refers to the set of approaches, decision making styles and practices used by entrepreneurs and managers to behave entrepreneurially (Tang et al., 2009). Wiklund \& Shepherd (2003) consider EO as a firm-level strategy formulation process used by firms to carry out the central purpose of an organization, strengthen its vision, and create a competitive advantage. Also, numerous studies (Wiklund \& Shepherd, 2005; Li et al., 2009; Hughes \& Morgan, 2007) have shown that high EO firms outperform those with low EO. Hence EO is noted as firm-level strategic formulation process that businesses use to achieve a competitive advantage (Van Geenhuizen et al., 2008).

Furthermore, the external environment in which firms operate in has been identified as a significant factor that influences EO (Davis, 2007). This is because external environmental factors are capable of affecting the failure and success of businesses. Gathungu et al. (2014) expound that the external environment, gauged in terms of environmental munificence (i.e. favourable environmental conditions) or hostility (i.e. unfavourable environmental conditions), offers both opportunities and multifaceted challenges which businesses need to respond to in a creative manner. Kuratko \& Hodgetts (2004) established that external factors could directly and or indirectly influence the entrepreneurial competence and performance of the business. Jabeen \& Mahmood (2014) stress that in order for businesses to take advantage of the opportunities from the dynamic and competitive business environment; businesses need to refigure their existing strategies. Hence, in order for businesses to maintain their competitive edge and survive in this new business environment, they have to constantly examine their internal and external environment to identify threats and take advantage of opportunities (Ramlall, 2002).

Prior studies (Miller \& Friesen, 1982; Wiklund \& Shepherd, 2005), suggest that EO is not applicable in all environments. Consequently, the magnitude of the EO- performance nexus is reliant on the external environmental factors (Tang et al., 2009).While, a there exist a multiplicity of studies on the EO-performance nexus, interestingly; the findings have not been consistent. For example, while some scholars present strong 
evidence on the positive impact of EO on performance (e.g. Baker \& Sinkula, 2009; Kaya, 2009; Naldi et al., 2007; Nelson \& Coulthard, 2005; Rauch et al., 2009), others found no significant relationship (e.g. Frank et al., 2010), and yet another studies by Arbaugh et al. (2009) have showed mixed results. Lumpkin and Dess (1996) expound that the EO-performance nexus does not provide the full picture of the relationship and as such, more research is required to test the mediating and moderating effects of several factors on the EOperformance nexus to provide a more accurate depiction of performance outcomes. Over the years, researchers have widely examined EO under several control circumstances and moderating effects of environmental factors such as the industry or business environment such as dynamism, heterogeneity, and hostility of the firm (Lumpkin \& Dess, 2001; Wiklund \& Sheperd, 2005; Nelson \& Coulthard, 2005) and organizational factors such as structure or characteristics of founder; the availability of critical resources like financial and social capital and networks (Harms et al., 2010; Walter et al., 2006; Wiklund \& Shepherd, 2005) in many industry contexts. As far the external environment is concerned, Martins and Rialp (2013) suggested that within the premises of contingency theory, external environment factors has been identified as a key moderating variable for any successful strategy implementation. However, the construct of environmental hostility has not been extensively tested empirically by prior studies in South Africa. As such, it becomes important to research this construct as it will help uncovers fruitful insight on how SMEs in South Africa and other developing regions can refigure their existing strategies in the current competitive market, to enable them to seize opportunities and maintain their competitive edge. Consequently, the objective of this study is to determine the impact of EO on SME performance, as well as to examine the moderating influence of environmental hostility on the EO- performance relationship.

\section{Literature Review}

Entrepreneurial Orientation: EO has emerged over the years to become one of the most widely studied concepts in the field of entrepreneurship and business management. EO was put forth by Miller (1983) as comprising of three dimensions namely: innovativeness, proactiveness and risk taking. He explicated that these three dimensions of EO act together and "comprise a basic uni-dimensional strategic orientation" and therefore should be combined when conducting entrepreneurship research. As an extension to the three dimensional EO model, Lumpkin \& Dess (1996) added two other factors (autonomy, and competitive aggressiveness) to form a five dimensional EO model. These five EO dimensions are believed to vary independently and thus recognize the multi-dimensionality of the EO construct where in businesses can have different combinations of these five dimensions

Dimension of E0: While a vast number of studies (Fatoki, 2014; Ferreira \& Azevedo, 2008; Tirfe \& Kassahun, 2014; Beliaeva, 2014; Rauch et al., 2009; Tang et al., 2009) have focused consistently on the three dimensions of EO, very limited studies have used all these five dimensions of EO (e.g. Hughes \& Morgan, 2007; Callaghan \& Venter, 2011; Kusumawardhani et al., 2009). This paper acknowledges that the five dimensions that are critical to EO are: innovation, pro-activeness, risk taking, competitive aggressiveness, and autonomy and as such all of them will be considered in this paper.

Innovativeness: Schumpeter (1934) was one of the pioneering researchers to acknowledge the key part played by innovation in the entrepreneurial process with regards to creating, developing and introducing new products, systems, processes and organizational structures. Lumpkin \& Dess (1996:142) define innovation as "the firm's tendency to engage in, and support new ideas generation, novelty, experimentation, and creative process or research and development activities which may result in new products, services, or technological processes". These researchers further view innovativeness as the firm's willingness to open its organisational culture to new and creative ideas and depart from existing practices and technologies. Innovativeness has been identified as a significant source of growth for a firm (Dess \& Lumpkin, 2005). Kropp et al. (2006) identified innovativeness as a vital factor for new business success. Researchers (Lumpkin et al., 2010; Piirala 2012) have established that innovativeness is necessary in sustaining a firm's viability as it is the generation of new ideas that lead to the improvement and or development of new products/markets that help in the sustainability of the business. This is because innovativeness helps in the improvement and or development of new products/markets necessary to deal with the rapid and continuously changing and uncertain environment in which businesses operate (Quaye \& Acheampong, 2013). Moreover, Ngoze, \& Bwisa 
(2014), established that the innovativeness has positive impact on financial performance. Hence, based on the above discussion, it is hypothesized that innovativeness will positively influence SME performance.

Hypothesis 1: Innovativeness has a positive relationship with SME performance

Proactiveness: Proactiveness refers to how a business responds to market opportunities by developing an opportunity-seeking outlook whereby new products and services are introduced far ahead of competitors as a means of increasing the firm's competitive posture (Kreiser et al., 2002; Lumpkin \& Dess, 2001).Proactiveness has been conceptualised as a mindset that focuses on identifying and evaluating new opportunities, monitoring the market trends and establishing new venture teams when anticipating for future demand and shaping the business environment (Lumpkin \& Dess, 2001). These researchers also found proactiveness to have a positive impact on each of the performance measures. Dess \& Lumpkin (2005) expounds that a proactive firm is able to identify and anticipate possible emerging problems and find solutions for them, which in turn acts as key competitive advantage, because competitors need to respond to the successful initiatives of the pioneer. Quaye \& Acheampong (2013) pointed out that proactiveness is a significant EO dimension because of its forward-looking perspective. Ngoze\& Bwisa (2014) established that the proactiveness has positive impact on financial performance. Also, Ambad \& Wahab (2013) found that in Malaysia, environmental hostility positively moderated the relationship between proactiveness, risk taking and firm performance. Furthermore Gurbuz \& Ayko (2009) observed proactiveness to have a significant positive influence on sales and employment growth. Moreover, Wang \& Yen (2012) showed that proactiveness has a positive effect on the sales of the firms among Taiwanese SMEs in China. Hence following this line of discussion, it is hypothesised that proactiveness will positively influence SME performance.

\section{Hypothesis 2: Proactiveness has a positive relationship with SME performance}

Risk taking: Ogunsiji \& Kayode (2010: 195) define risk taking as "the capacity of the entrepreneur to perceive risk at its inception and to find avenues to mitigate transfer or share the risk". Risk taking is also seen as the inclination of a firm to get involved in risky projects that have a high level of uncertainty with unknown outcomes and success probability, as a means of achieving the firm's objectives (Beliaeva, 2014; Miller, 1983). Lumpkin \& Dess (2001) identified risk taking as one of the component of EO and a unique characteristic of entrepreneurial behaviour (Quaye \& Acheampong, 2013). Timmons \& Spinelli (2008) point out that risk taking is an intrinsic part in the creation of an entrepreneurial venture and the willingness to take this risk results in a potential reward. Kreiser et al. (2002) found that entrepreneurial firms were higher risk takers than non-entrepreneurial firms and also adopted a highly proactive approach in their quest for new opportunities. Also, Owoseni \& Adeyeye (2012) observed risk-taking has a significant relationship with perceived SME performance. Moreover, Ngoze \& Bwisa (2014) established that the risk taking has positive impact on financial performance. Hence, we expected that risk taking will have a positive relationship with SME performance.

Hypothesis 3: Risk taking has a positive relationship with SME performance

Competitive aggressiveness: Competitive aggressiveness is defined as "a firm's capacity to outweigh and be a head of rivals at grasping every opportunity" (Ogunsiji\& Kayode, 2010:195). These researchers further see competitive aggressiveness as the freedom to work on one's ideas and initiatives. While competitive aggressiveness has been considered and examined as an attribute of pro-activeness (Razak, 2011).Lumpkin \& Dess (1996) stress that these two dimensions of EO vary as competitive aggressiveness focuses on how a business deals with existing trends and market conditions in relation to its competitors while proactiveness focuses on a firm's quest for new market opportunities. Le Roux \& Bengesi (2014) point out that given that SMEs operate in a fast-changing and intense worldwide competitive environment, competitive aggressiveness is required to maintain a competitive market posture given that consumers are exposed to a diverse range of products and services resulting in changing consumer tastes and preferences. As such competitive aggressiveness can be used as a driving mechanism to withstand the fierce competition and respond appropriately to existing and emerging competitive threats. Furthermore, Ngoze \& Bwisa (2014) established that the competitive aggressiveness has a positive impact on financial performance. Hence following this line of discussion, it is hypothesised that competitive aggressiveness will have a positive relationship with SME performance.

Hypothesis 4: Competitive aggressiveness has a positive relationship with SME performance 
Autonomy: Lumpkin \& Dess (1996:136) view autonomy as "the independent action of an individual or a team in bringing forth an idea or a vision and carrying it through to completion". Autonomy can also be considered as the strong desire a person has to freely develop and implement his/her idea (Lumpkin et al., 2009). Coulthard (2007) identified autonomy as a vital factor in improving the performance of a business across different industries. Also, several researchers (Kusumawardhani et al., 2009; Covin et al., 2006; Rauch et al., 2009) are of the opinion when employees are given autonomy, they will be entice to act entrepreneurially and thus will help to enhance the performance of the business. Ngoze \& Bwisa (2014) established that autonomy has positive impact on financial performance. Nonetheless, Davis (2007) fails to find a positive association between autonomy and SMEs performance. However, we expected autonomy to have a positive relationship with SME performance.

Hypothesis 5: Autonomy has a positive relationship with SME performance

Environmental Hostility as a moderating factor: The influence of environmental variables has always been acknowledged as an important moderating factor in the relationship between EO and performance (Davis, 2007). The three environmental moderating factors acknowledged by prior EO studies are environmental munificence, environmental dynamism and environmental hostility but this study will only focus on environmental hostility. Khandwalla (1977) considers an environment to be hostile when it is risky and stressful, with few opportunities. Miller \& Friesen (1982) defined hostility as" the degree of threat to the firm posed by the multifacetedness, vigor and intensity of the competition and the downswings and upswings of the firm's principal industry". Covin \& Slevin (1989) point out that hostility is usually displayed by the degree of threat a business faces and also characterised by intense competition, lack of business opportunities, overwhelming business climate and unsafe industry setting.

Prior studies that have examined the moderating role of environmental hostility on E0 provided mixed findings. For example, while some studies (Mu \& Benedetto, 2011; Zahra \& Garvis, 2000; Martins \& Rialp, 2013; Covin et al., 2006), have reported a strong empirical support for a positive relationship; other scholars (Becherer \& Maurer, 1997; George et al., 2001) established a negative relationship; while some researchers have produced inconclusive findings (Covin \& Slevin, 1989).With regards to E0 dimensions, Gathungu et al. (2014) observed that environmental hostility threatens the survival and viability of a business. This is because a hostile environment negatively affects innovative activities within a business. Hostile markets are characterized by fierce competition, scarce resources and low levels of industry profitability and thus it is most possible that any business employing an overly innovative attitude will overextend them instead of conserving their limited resources. Kreiser et al. (2002) found a negative association between innovation and hostility, which is congruent with theoretical beliefs by Zahra \& Bogner (2000: 165), who stated that "intense hostility in these markets might make aggressive gambling of new ventures' limited financial resources by offering radically innovative products a poor strategic choice". With regards to risk taking, Zahra \& Garvis (2000) pointed out that while risk-taking would enhance the performance of businesses in moderately hostile environments, in extremely hostile environments businesses will be discouraged from taking unnecessary risks as it would erode the profits of the business. Goll \& Rasheed (1997) also established that in hostile environment, the lack of resources would "lead firms to avoid excessive risk-taking and pay greater attention to the conservation of resources". As such, Zahra \& Garvis (2000) posit that in excessively hostile environments businesses refrain from taking unnecessary risks.

Furthermore, Lumpkin and Dess (2001) established that the moderating effect of environmental hostility on proactiveness-performance nexus is usually unfavourable. This is because in hostile environment; the intensity of competition amongst rivalry puts more pressure on a business and thus necessitates a greater need for these businesses to interact amongst each other in order to create a more efficient business. Also, businesses refrain from experimenting on new strategies since hostile environment forces businesses to be more focused on conserving their limited financial resources. Committing limited resources to manage threats is adversative to the vital role experimentation and discovery play in enhancing proactiveness. With regards to competitive aggressiveness, Porter (1980) pointed out that businesses competing in fiercely competitive industries need to "tightly managed decentralization" and "strategic discipline". Also, given that there is a limited amount of decision making and strategic options amongst businesses competing in fiercely competitive industries, the limited availability or the lack of organization slack becomes less dreadful. Consequently, when environmental hostility is high, one will expect that businesses that are competitive 
aggressiveness to have a high business performance, as opposed to when environmental hostility is low. At the same time, while autonomy will entice employees to act entrepreneurially, which will in turn enhance the performance of the business; in a hostile environment given that resources are scare and there is a low level of industry profitability; businesses are forces to be more focused on conserving their limited financial resources and thus only projects which are deemed highly necessary will be completed. Hence, this study hypothesizes:

Hypothesis 6a: The Innovativeness-performance relationship will be negatively moderated by environmental hostility

Hypothesis 6b: The Proactiveness- performance relationship will be negatively moderated by environmental hostility

Hypothesis 6c: The Risk taking- performance relationship will be negatively moderated by environmental hostility

Hypothesis 6d: The competitive aggressiveness - performance relationship will be positively moderated by environmental hostility

Hypothesis 6e: The autonomy - performance relationship will be positively moderated by environmental hostility

\section{Methodology}

In this study a quantitative approach was adopted to measure the effects of EO (innovativeness, risk-taking, proactiveness, autonomy and competitive aggressiveness) on SME performance, as well as to examine the moderating effect of environmental hostility on the EO-performance relationship in South Africa. Data was collected using self-administered questionnaires. The sample consists of entrepreneurs in the Mangaung metropolitan municipality in the Free State province of South Africa. The Yellow pages directory was used to identify entrepreneurs owing to the lack of a database of entrepreneurs in the Free State and South Africa in general. Convenience sampling method was adopted and supplemented with snowball sampling. Convenience sampling was used because of the ease of accessibility of the respondents identified from the Yellow pages directory. The respondents which were identified from the Yellow pages directory were then visited at their specific business locations. Snowball sampling was then applied on the initial respondents as they refereed the researchers to other entrepreneurs operating in the Mangaung metropolitan municipality. A total of 300 questionnaires were distributed to the entrepreneurs and a 3 weeks period was given for them to answer the questionnaire. In other to increase the response rate, follow up call were made to the entrepreneurs to remind them to complete the questionnaire. Out of the 300 questionnaires that was issued, 270 was received from the entrepreneurs, but only 200 were fully completed and thus yielding a $66.7 \%$ valid response rate.

\section{Variables and measures}

Entrepreneurial Orientation and its dimensional variables: Prior studies have measured EO using either a one-dimensional or multidimensional construct (Alarape, 2013; Covin \& Wales, 2011; Hughes and Morgan, 2007; Fatoki, 2014; Lumpkin and Dess, 1996). In this study, the Hughes and Morgan (2007) and Ofem (2014) multidimensional scale was adopted consisting of eighteen items of which three items each were used to form the sub-scales for innovativeness, competitive aggressiveness, proactiveness, and risk taking, while six items were used to form autonomy. In this study, the original Hughes and Morgan (2007) scale consisting of eighteen items and structured in a seven-point Likert-type scale were reconstructed to a five-point Likerttype scale ranging from strongly disagree (1) to strongly agree (5) as used in prior studies (e.g. Alarape, 2013; Fairoz et al., 2010). This study adopted this approach so as to classify SMEs as having a low, moderate, or high level of EO, as explained by Alarape (2013), where SMEs with an EO less than or equal to 3 are considered as having a low EO; SMEs with an EO greater than or equal to 3 but less than 4 are classified as having a low EO; SMEs with an EO greater than or equal to 3 but less than 4 are categorized as having a moderate level of EO; and SMEs with an EO of four and above are classified as having a high level of EO.

Control Variable: A firm's age indicates the number of years the business has been operational. In this study, the age of the business was used as a control variable, as used by prior studies (e.g. Hameed \& Ali, 2011; Zahra \& Garvis, 2000). 
Environmental Hostility: Environmental hostility which is the moderating variable was measured using Miller \& Friesen (1982) three item scale, as used in prior studies (Ambad \& Wahab, 2013; Muhanna, 2006; Martins \& Rialp, 2013; Zahra \& Garvis, 2000). The three item scale was structured in a five-point Likert-type scale ranging from strongly disagree (1) to strongly agree (5).In order to get a composite index of environmental hostility, an average rating for each of the three questions was taken. Also, the higher the index, the more hostile the environment in which the business is operating in.

Firm performance: A combination of financial and nonfinancial variables was used in measuring SME performance. Owing to the fact that the SMEs owners were not willing to disclose their financial information, self-reported data was used to obtain information. The different measures used following previous studies (Hameed and Ali, 2011; Lysons and Farrington, 2012; Ong \& Ismail, 2012) are (sales revenue, profits, number of employees, growth in market share and customer satisfaction).

\section{Results}

Profile of Respondents: Two hundred and eighty five questionnaires were distributed to SME ownermanagers of which 200 were fully completed and returned (i.e. $70.1 \%$ response rate). The majority of respondents were males (68\%) compared to females (32\%). Also, $48 \%$ of the respondents were between the ages of 31 and 40 ; and $29 \%$ of respondent between the ages of 21-30. The majority of the respondent (70\%) came from entrepreneurial families. Furthermore, more than fifty percent of the SME owner-managers had only attained an educational level up to matric. Moreover, Cronbach's alpha was used to examine the internal consistency of the variables for EO and environmental hostility. The following alpha values, 0.912, 0.904, $0.859,0.705,0.756$ and 0.757 were obtained for risking taking propensity, proactiveness, innovativeness, autonomy, competitive aggressiveness and environmental hostility respectively. As such, all the constructs were considered to have a high level of internal consistency (alpha $>0.7$ ). This thus validated the use of these measures for the analyses performed below.

Table 1: Correlation Matrix

\begin{tabular}{|c|c|c|c|c|c|c|c|c|c|c|c|}
\hline & & $\begin{array}{l}\text { Mea } \\
\text { n }\end{array}$ & S.D. & 1 & 2 & 3 & 4 & 5 & 6 & 7 & 8 \\
\hline 1 & $\begin{array}{l}\text { Risk taking } \\
\text { propensity }\end{array}$ & 3.57 & 0.97 & 1 & & & & & & & \\
\hline 2 & Proactiveness & 2.05 & 0.90 & $-0.64^{* *}$ & 1 & & & & & & \\
\hline 3 & Innovativeness & 2.63 & 0.70 & $-0.41^{* *}$ & $0.90^{* *}$ & 1 & & & & & \\
\hline 4 & $\begin{array}{l}\text { Competitive } \\
\text { aggressiveness }\end{array}$ & 2.06 & 0.31 & $0.32 * *$ & $0.27^{* *}$ & $0.45^{* *}$ & 1 & & & & \\
\hline 5 & Autonomy & 3.61 & 0.60 & $-0.47^{* *}$ & $0.62^{* *}$ & $0.60^{* *}$ & $0.28^{* *}$ & 1 & & & \\
\hline 6 & $\begin{array}{l}\text { Environmental } \\
\text { Hostility }\end{array}$ & 4.13 & 0.36 & -0.01 & $0.67^{* *}$ & $0.75^{* *}$ & $0.69 * *$ & $0.39 * *$ & 1 & & \\
\hline 7 & Age (Log) & 0.76 & 0.35 & -0.03 & -0.04 & -0.10 & -0.05 & 0.03 & -0.12 & 1 & \\
\hline 8 & Performance & 2.87 & 054 & 0.05 & -0.14 & $0.21 *$ & -0.01 & $0.18^{*}$ & -0.14 & -0.13 & 1 \\
\hline
\end{tabular}

** Sig at $1 \%,{ }^{*}$ Sig at $5 \%$,

Table 1 depicts the descriptive information and correlation matrix for the different E0 dimensions, environmental hostility, SME performance, and the age of the business. Looking at the EO dimensions, it is observed that SMEs have a moderate level of risking taking propensity (Mean=3.57) and autonomy (mean= 3.61 ) and a low level of proactiveness (mean=2.05), innovativeness (mean=2.63) and competitive aggressiveness (2.06). These findings are congruent by the study by Yoon (2012) who established that SMEs had moderate levels of risk taking propensity. Likewise, Fairoz et al. (2010) showed that SMEs had low levels of proactiveness. Also, the results depict that the mean score for environmental hostility is 4.13, suggesting the SMEs in South Africa operate in a hostile business environment. This is congruent to the view by the Business Environment specialist (2014) that South African SMEs continue to face an extremely hostile business environment. 
Journal of Economics and Behavioral Studies (ISSN: 2220-6140)

Vol. 8, No. 6, pp. 6-18, December 2016

Table 2: Results on the moderating of Environmental Hostility effect on EO Dimensions construct

\begin{tabular}{|c|c|c|c|c|c|c|c|c|}
\hline \multirow[t]{2}{*}{ Factors } & \multicolumn{2}{|c|}{ Model 1} & \multicolumn{2}{|c|}{ Model 2} & \multicolumn{2}{|c|}{ Model 3} & \multicolumn{2}{|c|}{ Model 4} \\
\hline & Beta & T-Value & Beta & T-value & Beta & T-value & Beta & T-value \\
\hline \multicolumn{9}{|l|}{ Control Variables } \\
\hline Constant & & $33.312^{* *}$ & & $10.098^{* *}$ & & $10.271^{* *}$ & & $4.664^{* *}$ \\
\hline Log (Age) & -0.128 & -1.809 & -0.128 & -1.827 & -0.144 & $-2.047^{*}$ & -0.191 & $-2.648^{* *}$ \\
\hline \multicolumn{9}{|l|}{ Independent Variables } \\
\hline \multicolumn{9}{|l|}{ propensity (RT) } \\
\hline Proactiveness (PR) & & & -0.217 & -0.989 & -0.014 & -0.055 & -0.582 & -1.782 \\
\hline Innovativeness (IN) & & & -0.033 & -0.174 & -0.012 & -0.062 & 0.139 & 0.611 \\
\hline $\begin{array}{l}\text { Competitive } \\
\text { aggressiveness (CA) }\end{array}$ & \multicolumn{7}{|c|}{ aggressiveness (CA) } & $3.379^{* *}$ \\
\hline Autonomy (AT) & & & 0.211 & $2.241^{*}$ & -0.224 & $-2.376^{*}$ & -0.186 & -1.165 \\
\hline \multicolumn{9}{|l|}{ Moderating Variables } \\
\hline Environmental & & & & & -0.255 & -1.642 & 0.129 & 0.554 \\
\hline \multicolumn{9}{|l|}{ Hostility (EH) } \\
\hline \multicolumn{9}{|l|}{ Interaction Items } \\
\hline RT x EH & & & & & & & -0.496 & $2.136^{*}$ \\
\hline PR x EH & & & & & & & 0.540 & 1.233 \\
\hline IN x EH & & & & & & & 0.053 & 0.168 \\
\hline $\mathrm{CA} \times \mathrm{EH}$ & & & & & & & 0.638 & $2.816^{* *}$ \\
\hline AT $x \mathrm{EH}$ & & & & & & & 0.392 & 1.541 \\
\hline \multicolumn{9}{|l|}{ Model Parameters } \\
\hline R2 & 0.016 & & 0.075 & & 0.088 & & 0.158 & \\
\hline Adjusted R2 & 0.011 & & 0.046 & & 0.055 & & 0.104 & \\
\hline F-Value (sig.) & $3.273(C$ & 072) & 2.612( & $19)^{*}$ & $2.644(($ & $.012)^{*}$ & 32.927 & $.001)^{* *}$ \\
\hline R2-Change & - & & 0.059 & & 0.013 & & 0.076 & \\
\hline F-Change & - & & 2.456( & $35)^{*}$ & 1.679( & 102) & 3.381( & $06)^{* *}$ \\
\hline
\end{tabular}

** Sig at $1 \%, *$ Sig at $5 \%$,

Moreover, the results show the correlation matrix of all the five constructs of EO, environmental hostility, firm's age, and performance to illustrate inter-relationships among these constructs. It is observed that proactiveness, innovativeness, competitive aggressiveness and autonomy are positively correlated to environmental hostility and they are all statistically significant at the $1 \%$ level. According to Covin \& Covin (1990) the positive correlation between competitive aggressiveness and environmental hostility suggest that in increasingly hostile environments, entrepreneurs are more inclined to adopt a more competitively aggressive strategy. This can therefore also be said for innovativeness, proactiveness, and autonomy as increasing these factors is vital for surviving in a hostile business environment. However, only risking taking does not have any significant relationship with environmental hostility. Also established is the fact that the firm age is negatively correlated to risk taking, proactiveness, innovativeness and environmental hostility, though the results are insignificant. This is congruent with Piirala (2012) who found no significant correlation between firm age and risk-taking amongst firms in Finland. In addition, this study observed that innovativeness and autonomy are positively correlated with SME performance at a 5\% level of significance. Hameed and Ali (2011) also established a significant positive correlation between innovativeness and firm performance. This supports the view that innovation is a vibrant component in the success of a business. Likewise, the findings are in line with the arguments by Coulthard (2007) that autonomy positively related to SME performance. Environmental hostility had a significant negative relationship with SME performance. This outcome is consistent with that by Zahra \& Garvis (2000) where environmental hostility was also observed to have a negative correlation with SME performance. 
The results on Table 2 show the moderating effect on EO Dimensions and firm performance. Model 1 included only the control variable (firm's age) and the result show that F-value is insignificant ( $p \geq 0.05)$. Zahra \& Garvis (2000) also used age as a control variable and established that age had a negative coefficient and was not statistically significant, which is congruent with the findings of this study. In Model 2, the control variable (firm age) and independent variables (RT, PR, IN, CA \& AT) were included. The probability of the F-value is significant $(\mathrm{p}<0.05)$, indicating that the overall model is significant and thus valuable in predicting firm performance. These results addressed hypothesis $\mathrm{H} 1$ to H5. The EO dimensions of Competitive aggressiveness, risk taking and autonomy have a significant positive influence on SME performance. The results for innovativeness and proactiveness were insignificant. Consequently, hypotheses $\mathrm{H} 1$ and $\mathrm{H} 2$ were not supported while hypotheses H3, H4 and H5 are supported. The outcomes for hypotheses $\mathrm{H} 1$ and $\mathrm{H} 2$ were unexpected as many studies (Gurbuz \& Ayko, 2009; Ngoze \& Bwisa, 2014; Wang \& Yen, 2012) have shown that innovativeness and proactiveness have a significant positive influence on firm performance. The outcomes for hypotheses H3, H4 and H5 are congruent with existing evidence. For example, several researchers (Ambad \& Wahab, 2013; Owoseni \& Adeyeye, 2012) and observed a significant positive relationship between risk-taking and perceived SME performance. Likewise, Le Roux \& Bengesi (2014) recorded a significant positive relationship between competitive aggressiveness and SME performance; while Ngoze \& Bwisa (2014) established that the risk taking, competitive aggressiveness, and autonomy dimensions of EO positively influenced the performance of a business.

In Model 3, the moderating factor (environmental hostility) was added to model 2. The results depict that the probability of the F-value is significant at the 5\% level, overall significance of the model. The addition of environmental hostility to the model had little or no effect on the overall model as its prediction power had no significant increase $\left(\mathrm{R}^{2}\right.$-change $=1.3 \%$; F-Change $\left.=1.679 ; \mathrm{p}>0.05\right)$. However, as expected, the relationship between environmental hostility and firm performance was negative albeit the results are not statistically significant. In Model 4, the control variable the interaction items (RT x EH; PR x EH; IN x EH; CA x EH and AT $\mathrm{x} E \mathrm{E}$ ) were included in the model. The probability of the F-value indicates that the overall model is significant $(\mathrm{F}=32.927 ; \mathrm{p}<0.05)$ thus making it a good EO predictor of firm performance. Likewise, the inclusion of the interaction factors significantly enhances the predictability of the model as indicated by the significance of the F-Change value. It is observed that the addition of interaction variables enhances the variance explained by the model by $7.6 \%$ (R $\mathrm{R}^{2}$-Change). This model addresses hypotheses $6 \mathrm{a}, 6 \mathrm{~b}, 6 \mathrm{c}, 6 \mathrm{~d}$, and $6 \mathrm{e}$. Environmental hostility showed a significant moderating effect only for competitive aggressiveness $(\beta=0.638 ; \mathrm{P}<0.05)$ and risk taking propensity $(\beta=-0.496, p<0.05)$. This indicates that environmental hostility has a positive moderating effect on the relationship between competitive aggressiveness and firm performance and a negative moderating effect for the risk taking - performance relationship. Consequently, only hypotheses $6 \mathrm{c}$ and $6 \mathrm{~d}$ were supported. The moderating effect graphs for competitive aggressiveness and risk taking propensity are presented below to help in the interpretation of the moderating effects.

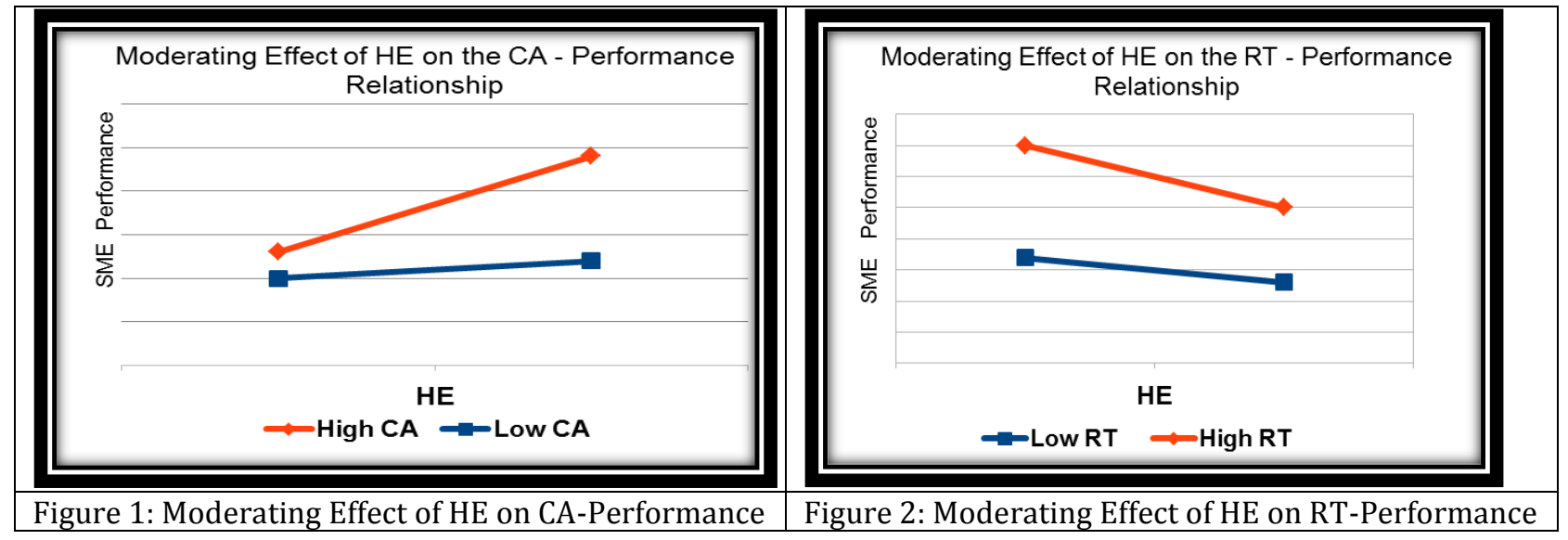

Figure 1 indicates the interaction between competitive aggressiveness and environmental hostility. As seen in Figure 1, businesses that have a high level of competitive aggressiveness tend to outperform those with a low level of competitive aggressiveness and this performance significantly increases when the business 
environment is highly hostile. This is in line with the arguments by Lunmpkin \& Dess (2001) that the competitive aggressiveness of a firm will often be intensely related to superior firm performance in moments of substantial environmental hostility compared to when such hostility is minimal. Figure 2 depicts that interaction between risk taking propensity and environmental hostility. Generally, firms with high risk taking propensity perform better than firms with low risk taking propensity; however, the level of performance decreases as the environment becomes more hostile. This shows that risk taking is more intensely related with superior during periods of minimal environmental hostility as oppose to periods characterized by high hostility. This is in line with the findings by Zahra \& Garvis (2000) who explicated that risk taking enhances firm performance when the environment is less hostile as most businesses refrain from taking risk during periods of high environmental hostility.

Managerial Implications: It is widely accentuated that one way of improving the performance of a business is by adopting an appropriate entrepreneurial behaviour. It is in this light that EO has grown in significance as an essential construct imperative in understanding how SME perform, grow, and succeed. The fact that only some of the EO Dimensions significantly influences SME performance suggest that at different phases of development EO dimensions might have an unequal importance in fostering firm performance. This is congruent with the views of Lumpkin and Dess (1996) who posit that different EO dimensions affect firm performance differently at any given phase of the firms' lifecycle. Consequently, businesses need not necessarily adopt all of the EO dimensions and should not also assume that each adopted EO dimension will significantly enhance the performance of the business. Also, the findings from this study depict strong evidence that a hostile business environment has a direct influence on the level of entrepreneurial behaviour exhibited by SMEs. Since SMEs in South Africa and many other developing countries operate in hostile business environments, the findings from this study provide valuable managerial implications to guide SME owners on strategies to adopt in enhancing their business performance and competitive posture. Converse to existing evidence innovativeness and proactiveness were seen to have no notable influence on firm performance while the other three EO dimensions showed a significant positive impact on SME performance. This is particularly important in South Africa and other developing countries given that most EO literature has focused mostly on the three dimensional model of EO (Risk taking propensity, innovativeness, and proactiveness) with little attention paid to competitive aggressiveness and autonomy. As such, since competitive aggressiveness and autonomy has been less investigated in EO literature in South Africa and other similar economies, the outcome of this study provides SME owners with new insights on EO dimensions that can help them to enhance the performance of their SMEs.

Moreover, while the findings affirm the positive influence of risk taking on SME performance, it is also seen that this relationship is negatively moderated by environmental hostility. Since risk taking might not be very profitable in periods of high environmental hostility (Zahra \& Garvis, 2000), it is important for entrepreneurs in regions with high environmental hostility such as South Africa to be strategic risk takers and cautiously monitor and calculate the level of risk they can be able to take without eroding the profits of the business. However, where environmental hostility is low to moderate, entrepreneurs should adopt risk taking as a vital strategy for enhancing performance. This is because conducting business in hostile and unstable environments is very different from conducting business in stable and favourable environments (Ambad and Wahab, 2013) and thus necessitates the use of different business strategies for both markets to avoid jeopardizing the survival of one's business. Additionally, it is also observed that environmental hostility positively moderates the association of competitive aggressiveness with SME performance. As such, as entrepreneurs adopt competitive aggressiveness as a strategy for enhancing performance, they should be vigilant in examining the business environment such that as environmental hostility increase, they also increase the competitive aggressiveness of their businesses. The correlation results confirmed the views of Covin \& Covin (1990) that businesses increase their competitive aggressiveness with increasing environmental hostility. This enables the business to remain competitive and effectively respond to threats from the external business environment.

\section{Conclusion}

In conclusion, the study showed that while innovativeness and proactiveness do not have a significant effect on SME performance; risk taking propensity, competitive aggressiveness, and autonomy have a significant 
positive effect on SME performance. It was also seen that while the risk taking-performance relationship is negatively moderated by environmental hostility, the competitive aggressiveness-performance relationship is positively moderated by environmental hostility. This study has provided valuable insights and shed more lights into how hostile environmental conditions influence entrepreneurial behaviors in South African SMEs. Findings from this study clearly posit that the environment plays a vital role in determining the EO levels in SMEs. The study showed that less investigated EO dimensions like autonomy and competitive aggressiveness were vital strategies for enhancing SME performance. Moreover, implications of environmental hostility as a moderating factor in the competitive aggressiveness and performance nexus as well as the risk taking performance relationship were discussed. While risk taking propensity is more strongly associated with high SME performance when environmental hostility is low, competitive aggressiveness on the other hand is more sturdily associated with superior SME performance when environmental hostility is high. This is because firms tend to increase their competitive aggressiveness when the business environment becomes more hostile however; firms revert to a more cautious risk taking approach during times of high environmental hostility to avoid eroding their profits in risky business decisions. This suggest the need for SMEs to always align their business strategies with appropriate EO dimensions to mitigate some of the negative consequences of operating in hostile business environments and enhance their business performance. It is imperative for future studies to take into consideration the differential role of the five sub-dimensions of EO when conducting research in hostile business environments.

\section{References}

Alarape, A. A. (2013). Entrepreneurial orientation and the growth performance of small and medium enterprises in Southwestern Nigeria. Journal of Small Business \& Entrepreneurship, 26, 553-577.

Alegre, J. \& Chiva, R. (2013). Linking Entrepreneurial Orientation and Firm Performance: The Role of Organizational Learning Capability and Innovation Performance.

Ambad, A. N. S. \& Wahab, A. K. (2013). Entrepreneurial Orientation among Large Firms in Malaysia: Contingent Effects of Hostile Environments. International Journal of Business and Social Science, 4 (16), 96-107.

Arbaugh, J. B., Cox, L. W. \& Camp, S. M. (2009). Is entrepreneurial orientation a Global construct? A multicountry study of entrepreneurial orientation, growth strategy, and performance. The Journal of Business Inquiry, 8(1), 12-25.

Baker, W. E. \& Sinkula, J. M. (2009). The complementary effects of market orientation and entrepreneurial orientation on profitability in small businesses. Journal of Small Business Management, 47(4), 443464.

Becherer, R. C. \& Maurer, J. G. (1997). The moderating effect of environmental variables on the entrepreneurial and marketing orientation of entrepreneur-led firms. Entrepreneurship Theory and Practice, 47-58.

Beliaeva, T. (2014). Antecedents and Performance Outcomes of Entrepreneurial Orientation: a Comparative Cross-Country Study. Master's Thesis: Saint-Petersburg State University / Lappeenranta University of Technology, Finland.

Callaghan, C. \& Venter, R. (2011). An investigation of the entrepreneurial orientation, context and entrepreneurial performance of inner-city Johannesburg street traders. Southern African Business Review, 15(1), 28-48.

Covin, J. G., Green, K. M. \& Slevin, D. P. (2006). Strategic Process Effects on the Entrepreneurial OrientationSales Growth Rate Relationship. Entrepreneurship Theory and Practice, 30, 57-81.

Covin, J. \& Slevin, D. (1989). Strategic management of small firms in hostile and benign environments. Strategic Management Journal, 10, 75-87.

Davis J. L. (2007). Firm-level entrepreneurship and performance: an examination and extension of relationships and measurements of the entrepreneurial orientation construct. Unpublished Thesis, University of Texas.

Dess, G. G. \& Lumpkin, G. T. (2005). The role of entrepreneurial orientation in stimulating effective corporate entrepreneurship. Academy of Management Executive, 19(1), 147-156.

Fairoz, F. M., Hirobumi, T. \& Tanaka, Y. (2010). Entrepreneurial orientation and business performance of small and medium scale enterprises of Hambantota District Sri Lanka. Asian Soc. Sci., 6(3), 34-46. 
Retrieved Dec. 18, 2012, from http://journal.ccsenet.org/index.php /ass/article/download/5374/4486.

Fatoki, O. O. (2014). The Entrepreneurial Orientation of Micro Enterprises in the Retail Sector in South Africa. Journal of Sociology and Social Anthropology, 5(2), 125-129.

Ferreira, J. \& Azevedo, G. S. (2008). Entrepreneurial orientation (EO) and growth of firms: key lessons for managers and business professionals. Problems and Perspectives in Management, 6(1), 82-88.

Frank, H., Kessler, A. \& Fink, M. (2010). Entrepreneurial Orientation and Business Performance - A Replication Study. Small Business Review, 6, 175-198

Gathungu, J. M., Aiko, M. D. \& Machuki, N. V. (2014). Entrepreneurial orientation, networking, external environment, and firm performance: a critical literature review.

Jabeen, R. \& Mahmood, R. (2014). Effect of External Environment on Entrepreneurial Orientation and Business Performance Relationship. Social and Basic Science Research Review, 2(9), 394-403.

George, G., Wood, Jr. D. R. \& Khan, R. (2001). Networking Strategy of Boards: Implications for Small and Medium-sized Enterprises. Entrepreneurship and Regional Development, 13(3), 269-285.

Goll, I. \& Rasheed, A. M. A. (1997). Rational decision making and firm performance: The moderating role of environment. Strategic Management Journal, 18, 583-591.

Gurbuz, G. \& Aykol, S. (2009). Entrepreneurial management, entrepreneurial orientation and Turkish small firm growth. Management Research News, 32(4), 321-336.

Hameed, I. \& Ali, B. (2011). Impact of Entrepreneurial Orientation, Entrepreneurial Management and Environmental Dynamism on Firm's Financial Performance. Journal of Economics and Behavioral Studies, 3(2), 101-114.

Harms, R., Reschke, H., Kraus, S. \& Fink, M. (2010). Antecedents of innovation and growth: analyzing the impact of entrepreneurial orientation and goal-oriented management. International Journal of Technology Management, 52(1-2), 135-52.

Hughes, M. \& Morgan, R. E. (2007). Deconstructing the relationship between entrepreneurial orientation and business performance at the embryonic stage of firm growth. Industrial Marketing Management, 36, 651-661.

Kaya, H. (2009). Entrepreneurial Orientation and Performance of Turkish Manufacturing FDI Firms: An Empirical Study, Faculty of Economics and Administrative Sciences Department of Management, 2009.

Khandwalla, P. N. (1977). The Design of Organizations. New York: Hareourt Brace.

Kreiser, M, P., Marino, D. L. \& Weaver, M. K. (2002). Reassessing the environment-EO link: the impact of environmental hostility on the dimensions of entrepreneurial Orientation. Academy of Management Proceedings

Kropp, F., Lindsay, N. \& Shoham, A. (2006). Entrepreneurial, market, and learning orientations and international entrepreneurial business venture (IEBV) performance in South African firms. International Marketing Review, 23(5), 504-23.

Kuratko, D. F. \& Hodgetts, R. M. (2004). Entrepreneurship: Theory, process, practice. OH: South-Western College Publishers, Mason

Kusumawardhani, A., McCarthy, G. \& Perera, N. (2009). Framework of entrepreneurial orientation and networking: a study of SMEs performance in a developing country. Proceedings of the Australian and New Zealand Academy of Management Conference (pp. 1-16). Adelaide, Australia: Australian and New Zealand Academy of Management.

Le Roux, I. \& Bengesi, M. K. (2014). Dimensions of entrepreneurial orientation and small and medium enterprise performance in emerging economies. Development Southern Africa, 31(4), 606-624.

Liu, H., Hou, J., Yang, P. \& Ding, X. H. (2011). Entrepreneurial orientation, organizational capability, and competitive advantage in emerging economies: evidence from China. African Journal Business Management, 5(10), 3891- 3901.

Lysons, K. \& Farrington, B. (2012). Purchasing and supply chain management. 8th edition. Harlow: Pearson Education Limited.

Lumpkin, G. T. \& Dess, G. G. (2001). Linking two dimensions of entrepreneurial orientation to firm performance: the moderating role of environment and industry life cycle. Journal of Business Venturing, 17, 429-451

Lumpkin, G. T., Cogliser, C. C. \& Schneider, D. R. (2009). Understanding and Measuring Autonomy: An Entrepreneurial Orientation Perspective. Entrepreneurship Theory and Practice, 2, 47-69. 
Martins, I. \& Rialp, A. (2013). Entrepreneurial orientation, environmental hostility and SME profitability: A contingency approach. Cuadernos de Gestión, 13(2), 67-88.

Miller, D. (1983). The correlates of entrepreneurship in three types of firms. Management Science, 29, 770791.

Miller, D. \& Friesen, P. H. (1982). Innovation in conservative and entrepreneurial firms: two models of strategic momentum. Strategic Management Journal, 3(1), 1-25.

Mohd, R., Yahya, K, K. \& Kamaruddin, H. B. (2012). The moderating effect of environment on the relationship between Self-Efficacy and Entrepreneurial Orientation among Malay SMEs in Manufacturing Industry. 2012 Cambridge Business \& Economic Conference, June 27- 28, Cambridge, UK.

Morgan, P. M., Danny, R. A. \& Donald, L. T. (1993). The Interrelationship between Environmental Hostility and Entrepreneurial Orientation. Journal of Applied Business Research, 9(4), 12-23.

$\mathrm{Mu}$, J. \& Benedetto, C. A. D. (2011). Strategic orientations and new product commercialization: mediator, moderator, and interplay. R\&D Management, 41(4).

Muhanna, E. (2006). Organisational Dynamics and its Influence on Firms' Entrepreneurship Ability: South Africa Perspective. Problems and Perspectives in Management, 4(4), 63-76.

Naldi, L., Nordqvist, M., Sjöberg, K. \& Wiklund, J. (2007). Entrepreneurial Orientation, Risk Taking, and Performance in Family Firms. Family Business Review, XX (1), 2007.

Nelson, B. \& Coulthard, M. (2005). The Impact of Entrepreneurial Orientation on Performance in Australian Franchise Firms, Monash University Business and Economics, Working Paper, 2005.

Ngoze, M. \& Bwisa, H. (2014). Entrepreneurial Orientation and Financial Performance of Manufacturing Firms in Developing Countries: are Kenya's Manufacturing Firms Exempted? (September 2, 2014)

Ofem, B. (2014). Entrepreneurial Orientation, Collaborative Networks, and Nonprofit Performance. Doctoral Dissertation, University of Kentucky, Lexington, United States

Ogunsiji, P. A. S. \& Kayode, W. L. (2010). Entrepreneurial Orientation as a Panacea for the Ebbing Productivity in Nigerian Small and Medium Enterprises: A Theoretical Perspective. International Business Research, 3(4), 192 -199.

Ong, W. J. \& Ismail, B. H. (2012). Entrepreneurial traits and firm serendipity-seeking on SMEs' performance: the effect of firm size. Journal of Enterprising Culture (JEC), 20(3), 265-286.

Owoseni, 0. 0. \& Adeyeye, C. T. (2012). The Role of Entrepreneurial Orientations on the Perceived Performance of Small and Medium-Scale Enterprises (SMEs) in Nigeria. International Business and Management, 5(2), 148-154.

Piirala, P. (2012). The impact of entrepreneurial orientation on firm performance: a comparative study of Finnish and German SMEs. Master's thesis, Aalto University School of Business, Finland

Porter, M. (1980). Competitive Strategy. New York: Free Press

Quaye, M. D. \& Acheampong, G. (2013). Are SME Owner-Managers Entrepreneurs? Evidence from Ghana. European Journal of Business and Management, 5(23), 37-47

Ramlall, S. J. (2002). Measuring Human Resource Management's Effectiveness in Improving Performance. Human Resource Planning, 26(1), 51

Rauch, A., Wiklund, J., Lumpkin, G. T. \& Frese, M. (2009). Entrepreneurial orientation and business performance: an assessment and past research and suggestions for the future. Entrepreneurship Theory and Practice, 33, 761-787.

Razak, A. R. (2011). Entrepreneurial Orientation as a Universal Remedy for the Receding Productivity in Malaysian Small and Medium Enterprises: A Theoretical Perspective. International Journal of Business and Social Science, 2(19), 249-257

Runyan, R., Drodge, C. \& Swinney, J. (2008). Entrepreneurial orientation versus small business orientation: what are their relationships to firm performance? Journal of Small Business Management, 46(4), 567588.

Schumpeter, J. A. (1934). The theory of economic development. Harvard University Press: Cambridge, MA.

Tang, Z., Kreiser, P. M., Marino, L., Dickson, P. \& Weaver, K. M. (2009). A Hierarchical Perspective of the Dimensions of Entrepreneurial Orientation. International Entrepreneurship and Management Journal, $5(2), 181-201$

Timmons, J. A. \& Spinelli, S. (2008). New Venture Creation. Entrepreneurship for the 21st Century, 7th edition. Boston, MA: McGraw-Hill/Irwin. Pp.250.

Tirfe, G. A. \& Kassahun, T. (2014). Entrepreneurial Orientation as Growth Predictor of Small Enterprises Evidence from Tigray Regional State of Ethiopia. Developing Country Studies, 4(11), 133-143. 


\section{Journal of Economics and Behavioral Studies (ISSN: 2220-6140)}

Vol. 8, No. 6, pp. 6-18, December 2016

Van Geenhuizen, M., Middel, R. \& Lassen, A. (2008). Corporate Entrepreneurship in SMEs during the Search for Discontinuous Innovations. [Online] Available: http:// v b n . a a u .d k / f i l e s / 14927322 / C o r p o r a t e _ Entrepreneurship_in_SMEs_during_the_Search_for_Discontinuous_Innovations.pdf (June 5, 2014).

Walter, A., Auer, M. \& Ritter, T. (2006). The impact of network capabilities and entrepreneurial orientation on university spin-off performance. Journal of Business Venturing, 21(4), 541-67

Wang, H. K. \& Yen, Y. F. (2012). An empirical exploration of corporate entrepreneurial orientation and performance in Taiwanese SMEs: a perspective of multidimensional construct. Total Quality Management \& Business Excellence, 23(9), 1035-1044.

Wiklund, J. \& Shepherd, D. (2003). Knowledge-based resources, entrepreneurial orientation, and the performance of small and medium sized businesses. Strategic Management Journal, 24(13), 13071314.

Wiklund, J. \& Shepherd, D. (2005). Entrepreneurial orientation and small business: a configurational approach. J. Bus. Vent., 20(1), 71-91.

Yoon, H. (2012). The Performance Effects of Entrepreneurial Orientation: Evidence from South Korean Startups. International Journal of Arts and Commerce, 1(4), 248-254.

Zahra, S. \& Garvis, D. (2000). International corporate entrepreneurship and firm performance: the moderation effect of international environmental hostility. Journal of Business Venturing, 15, 469492. 